\title{
Arte, diseño, medios: Memoriales de América Latina
}

Jorge La Ferla es investigador en artes y medios audiovisuales. Es Jefe de Cátedra de la Universidad de Buenos Aires y profesor titular de la Universidad del Cine. Ha curado exposiciones de arte tecnológico y programado muestras audiovisuales en América, Europa y Medio Oriente. Es Master in Arts y egresado del Programa Graduado del Centro de Estudios de América Latina de la Universidad de Pittsburgh y Licenciado en la Universidad de París VIII. Ha publicado libros sobre artes y medios audiovisuales en Argentina, Brasil y México. Sus últimos trabajos como autor, son: Cine (y) digital. Aproximaciones a posibles convergencias entre el cinematógrafo y la computadora (Manantial, 2009); neoTrópico. Caja Negra y otros microrrelatos junto a Gerardo Suter" (2018) y Circuito Alameda, junto a Gilbertto Prado (2019), Laboratorio Arte Alameda, Secretaría de Cultura, Instituto Nacional de Bellas Artes, México; y como compilador, Intermedia. Ensayos sobre una práctica académica, junto a Mariel Szlifman (2021). <jorgelaferla@gmail.com> Orcid: 0000-0001-8092-4024
Resumen En ocasión del Tercer Simposio DAT propongo un recorrido analítico por una serie de muestras que tuvieron lugar en América Latina que remiten a una memoria sobre las maneras de diseñar, representar y poner en obra problemáticas que hacen a lecturas críticas de nuestro continente. Son los diversos procesos artísticos que desde lo expositivo piensan significativamente y proponen relatos sobre nuestra región y sobre las mismas artes visuales tecnológicas. Un panorama analítico que comprende el cine experimental, la televisión, el video arte, el multimedia, el bioarte como parte de un conjunto que interpela y relaciona críticamente el arte contemporáneo con el diseño y arte mediático. Estos movimientos híbridos implican contaminaciones que trascienden las fronteras de los medios y que podemos considerar bajo el concepto de "extremidades discursivas" como lo define Christine Melo. Un recorrido por las obras de Albertina Carri y Andrés Denegri (Argentina), Gilbertto Prado (Brasil), José Alejandro Restrepo (Colombia), Gerardo Suter (México) e Irina Raffo (Uruguay) cuyos procesos he seguido de cerca ofrecen un muestrario significativo de lecturas del continente, las cuales dialogan con el contexto urbano en las cuales se desplegaron: Buenos Aires, México, Montevideo, Salta. Exposiciones que proponen una lectura de memorias personales, de relatos particulares por la historia reciente del continente y que referencian los medios aplicados en sendas muestras donde prima la práctica de la instalación la cual se despliega bajo diferentes soportes y dispositivos tecnológicos.

Palabras clave Arte, Diseño, Medios, América Latina. 


\section{Art, Design, Media: Memorials of Latin America}

Abstract On the occasion of the Third DAT Symposium, I propose an analytical journey through a series of exhibitions that took place in Latin America that refer to a memory on the ways of designing, representing and putting into work problems that make critical readings of our continent. They are the various artistic processes that, from the exhibition point of view, think significantly and propose stories about our region and about the same technological visual arts. An analytical panorama that includes experimental cinema, television, video art, multimedia, bio-art as part of a set that questions and critically relates contemporary art with design and media art. These hybrid movements involve contaminations that transcend the borders of the media and that we can consider under the concept of "discursive extremities" as defined by Christine Melo. A tour of the works of Albertina Carri and Andrés Denegri (Argentina), Gilbertto Prado (Brazil), José Alejandro Restrepo (Colombia), Gerardo Suter (Mexico) and Irina Raffo (Uruguay) whose processes I have closely followed offer a significant sample of readings of the continent, which dialogue with the urban context in which they were deployed: Buenos Aires, Mexico, Montevideo, Salta. Exhibitions that propose a reading of personal memories, of particular stories from the recent history of the continent and that refer to the means applied in each sample where the practice of installation prevails, which is deployed under different supports and technological devices.

Keywords Art, Design, Media, Latin America.

\section{Arte, Design, Mídia: Memoriais da América Latina}

Resumo Por ocasião do III Simpósio DAT, proponho um percurso analítico por meio de uma série de exposições realizadas na América Latina que remetem a uma memória sobre as formas de desenhar, representar e operacionalizar problemas que fazem leituras críticas de nosso continente. São os diversos processos artísticos que, do ponto de vista expositivo, pensam significativamente e propõem histórias sobre a nossa região e sobre as mesmas artes visuais tecnológicas. Um panorama analítico que inclui o cinema experimental, a televisão, a videoarte, a multimídia, a bioarte em um conjunto que questiona e relaciona criticamente a arte contemporânea com o design e a arte midiática. Esses movimentos híbridos envolvem contaminações que transcendem as fronteiras da mídia e que podemos considerar sob o conceito de "extremidades discursivas" conforme definido por Christine Melo. Um tour pelas obras de Albertina Carrie Andrés Denegri (Argentina), Gilbertto Prado (Brasil), José Alejandro Restrepo (Colômbia), Gerardo Suter (México) e Irina Raffo (Uruguai) cujos processos acompanhei de perto oferecem uma amostra significativa de leituras do continente, que dialogam com o contexto urbano em que foram implantadas: Buenos Aires, México, Montevidéu, Salta. Exposições que proponham uma leitura de memórias pessoais, de histórias particulares da história recente do continente e que se refiram aos meios aplicados em cada amostra onde prevalece a prática da instalação, que se desenvolve sob diferentes suportes e dispositivos tecnológicos.

Palavras-chave Arte, Design, Media, América Latina. 


\section{Introducción}

A partir de una serie de muestras que tuvieron lugar en América Latina propongo una memoria sobre las maneras de diseñar, representar y poner en obra problemáticas que hacen a lecturas críticas de América Latina. Es decir procesos artísticos que desde lo expositivo piensan significativamente relatos sobre nuestra región, y las artes visuales tecnológicas. La diversidad de nuestra geografía e historia, la producción de artes visuales en su heterogeneidad de estilos, medios y obras tanto como el contexto de cada país volverían complicado cualquier visión de conjunto. Sin embargo existen clasificaciones que señalan derroteros sobre las formas de tratar y representar un continente que exceden las categorías habituales de ejes temáticos o estéticos. Por cierto que el audiovisual siempre ha relevado lecturas significativas de una región en permanente crisis que a su vez remiten a un estado de situación de las mismas artes tecnológicas. En el siglo XX se comenzaron a establecer variadas problemáticas en común como por ejemplo el colonialismo, la dependencia económica, las dictaduras, las civilizaciones originales, los conflictos étnicos, los movimientos revolucionarios, la acción militante. Ahora sería el post colonialismo, la post pandemia, el post industrialismo, el neo liberalismo de ultra derecha entre otras vertientes sobre variados tópicos y las maneras de tratarlos formalmente. Por ejemplo en esta línea, se pensó el cine de nuestra de América Latina a través de las clasificaciones de cine militante, político, indigenista, tercer cine y el eterno retorno a la etiqueta del "nuevo cine", nacional o latinoamericano que ya parecen no responder a la riqueza de una producción que excede tales categorías. Sin embargo es evidente la necesidad de forjar estudios comparativos del continente que expandan lo que se investigó por ejemplo sobre el cine ampliándolo a otras categorías del audiovisual. En este panorama analítico es dable incluir al cine experimental, la televisión, el video arte, el multimedia, el bioarte pues formarían de un conjunto que interpela y relaciona críticamente el arte contemporáneo afirmando prácticas híbridas expandidas, lo que es el caso de estas exposiciones Estos movimientos implican contaminaciones que trascienden las fronteras de los medios y que podemos considerar bajo el concepto de "extremidades discursivas". ${ }^{1}$ Los significativos cambios en las materialidades, dispositivos, circulación, consumo del arte mediático marcan tendencia por las lecturas que ofrecen de América Latina. El campo de los estudios visuales nos remite a un paisaje mediático ${ }^{2}$ del continente, tanto como de las máquinas a través de las cuales se construye un discurso sobre la memoria del continente. Las

1 Nos remitimos a las investigaciones del colectivo brasileño, "Plataforma Extremidades", en relación a concebir diversos cruces de disciplinas para "el estudio crítico de las prácticas artísticas y mediáticas teniendo como principio la noción de extremidades. Es decir procedimientos de deconstrucción, contaminación e hibridez que conllevan procesos de subjetivación y resignificación de lenguajes" según lo define la estudiosa Christine Mello. www.extremidades.art (Consultado el 1.12.2021) 2 Machado, Arlindo: El paisaje mediático, Nueva Librería, Buenos Aires, 2007 
muestras personales de una serie de artistas en las que estuve involucrado en estos últimos años, implica volver a considerar tales exposiciones a una distancia temporal de su exposición. Un recorrido por las obras de Albertina Carri y Andrés Denegri (Argentina), Gilbertto Prado (Brasil), José Alejandro Restrepo (Colombia), Gerardo Suter (México) e Irina Raffo (Uruguay) cuyos procesos he seguido de cerca y que ofrecen un muestrario significativo considerando las diferentes lecturas del continente, las cuales dialogan con el contexto urbano en las cuales se desplegaron: Buenos Aires, México, Montevideo, Salta. Exposiciones que proponen una lectura de memorias personales, de relatos particulares por la historia reciente del continente y que referencian los medios aplicados en sendas muestras donde prima la práctica de la instalación la cual se despliega bajo diferentes soportes y dispositivos tecnológicos.

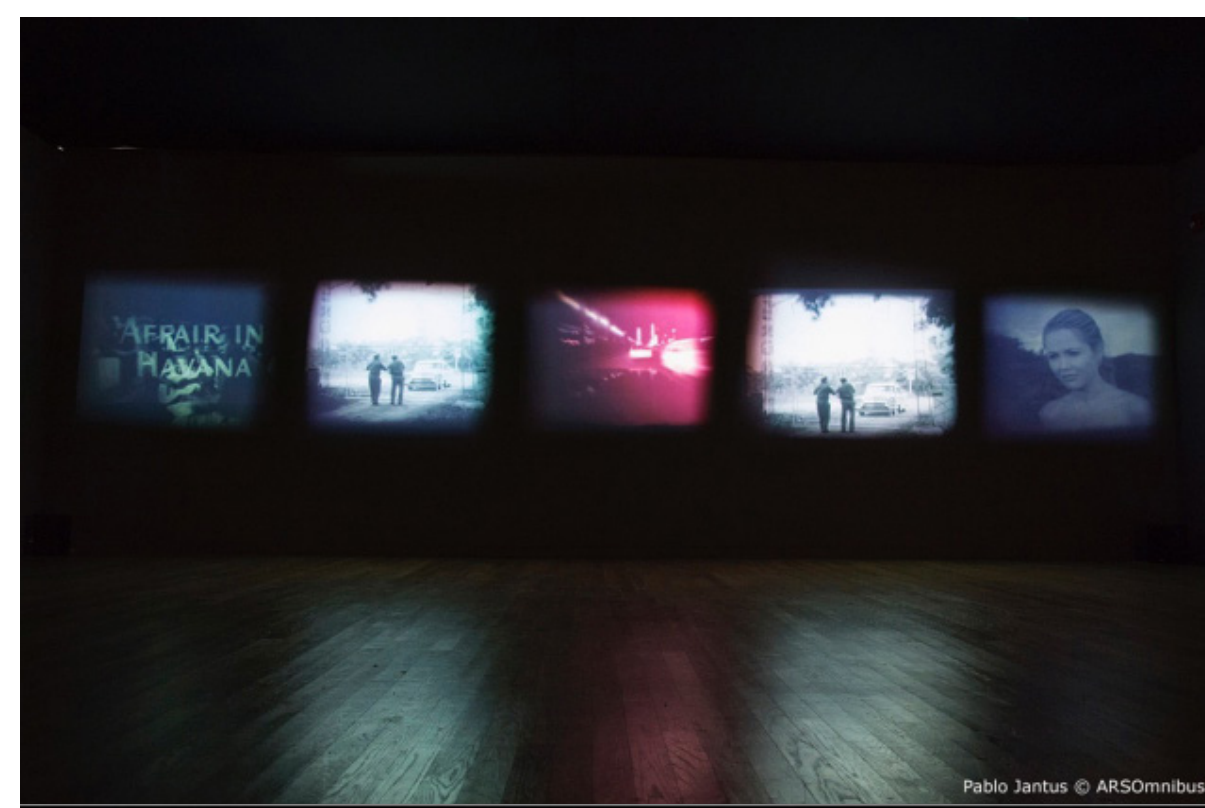




\section{Cines expandidos}

La realizadora argentina Albertina Carri despliega su trabajo entre el cine, la producción editorial y el arte contemporáneo en proyectos que se concretan en diversos objetos y prácticas artísticas. Carri es realizadora cine - ficción, documental, animación- y ha incursionado en la performance, el diseño y la literatura y ha expandido su trabajo al campo del arte contemporáneo. Su producción documental marca dos extremos entre los largometrajes Los rubios (2003) y Cuatreros (2018) ubicando al cine de no ficción en diversas variables expresivas que remiten a una memoria personal y un relato que remite a la última dictadura militar. Su primer largometraje documental, Los Rubios (2003), que se distancia de cualquiera de los modelos instaurados durante las primeras décadas del retorno a la democracia y de los urgentes relatos que surgieron sobre la dictadura y la violación de los derechos humanos en Argentina. En Los Rubios la combinatoria entre documental y ficción, la variedad de soportes y formatos - fílmicos y electrónicos-, la animación y el uso de la tipografía marcan una escritura que excede los formatos del documental clásico. Estos elementos hacen de Los Rubios un documental con un discurso diferente una relato personal y las maneras de rememoralos a través del audiovisual. Este proceso continuaría con publicación Los Rubios. Cartografía de una película (2007) ${ }^{3}$, antológico proyecto editorial que se sitúa entre el libro de artista y el ensayo. Pensado como una crónica que sigue los pasos de la puesta en escena de un film una vez terminado, se refiere a Los Rubios como proyecto a partir de ilustraciones, fotos e intervenciones. Un hipertexto que excede el film acabado y repasa su proceso creativo, como una forma de escritura que se concentra en la puesta en página editorial y el diseño gráfico que anuncia diversas continuaciones. Entre las cuales estuvo la muestra Operación fracaso y el Sonido recobrado que tuvo lugar en Buenos Aires en la sala PAyS del Parque de la Memoria ${ }^{4}$ la se concentró en los vestigios de datos, documentos y registros que provienen diversos medios articulados en una serie de video instalaciones, y obras objetuales en que la práctica de la instalación vuelve a sus orígenes de escultura expandida. Un eje de la muestra fue Investigación sobre cuatrerismo obra de cinco canales de video. El punto de partida de la idea era el libro de Roberto Carri, Isidro Velázquez. Formas Prerrevolucionarias de la Violencia (1968), manifiesto del pensamiento político y la acción revolucionaria, el cuál disparó una acción política, un pensamiento militante y numerosos proyectos fímicos sobre la épica de Isidro Velásquez ${ }^{5}$ según la visión del libro, escrito por el padre de Albertina, desaparecido junto a su mujer, durante la dictadura. Investigación sobre Cuatrerismo se presenta como un posible guion ${ }^{6}$ sobre esas películas fallidas, es decir, como un ensayo sobre

3 Carri, Albertina, Los Rubios. Cartografia de una película, BAFICI, Buenos Aires, 2007. $4 \mathrm{https}$ ://parquedelamemoria.org.ar/operacion-fracaso-y-el-sonido-recobrado/ (Consultado el 1.12.2021)

5 Albertina Carri y Mariano Llinás tenían proyectos fílmicos sobre el personaje que nunca se llevaron a cabo. En 1971, Pablo Szir realizó un film que pocos vieron y que se perdió. 6 Guión a la manera de Jean-Luc Godard, que produce varios videos, en forma de ensayo, sobre algunas de sus películas, una vez terminadas. 
ese film deseado por varios autores, entre los cuales se encuentra la misma Albertina. Un film que no fue, del cual quedan restos y memorias dispersas, y que las cinco pantallas de Investigación sobre el Cuatrerismo despliegan como un panorama visual sobre la operatoria de un film imaginario, cuyo registro y montajes son imposibles. De esta instalación se vincula la estructura de siguiente film de Carri, Cuatreros (2015) en dónde la composición de multipantallas en el cuadro puso en tensión los diversos archivos de cine y televisión de la época con la voz performática, elocuente y en off, de la realizadora. Un largometraje de archivos que se origina en una obra de arte contemporánea. Las imágenes analógicas de la época de los años 70, se convierten en un archivo digital y este funciona en dos dispositivos, el instalativo y el largometraje, que van del espacio de arte a la sala oscura del cine.
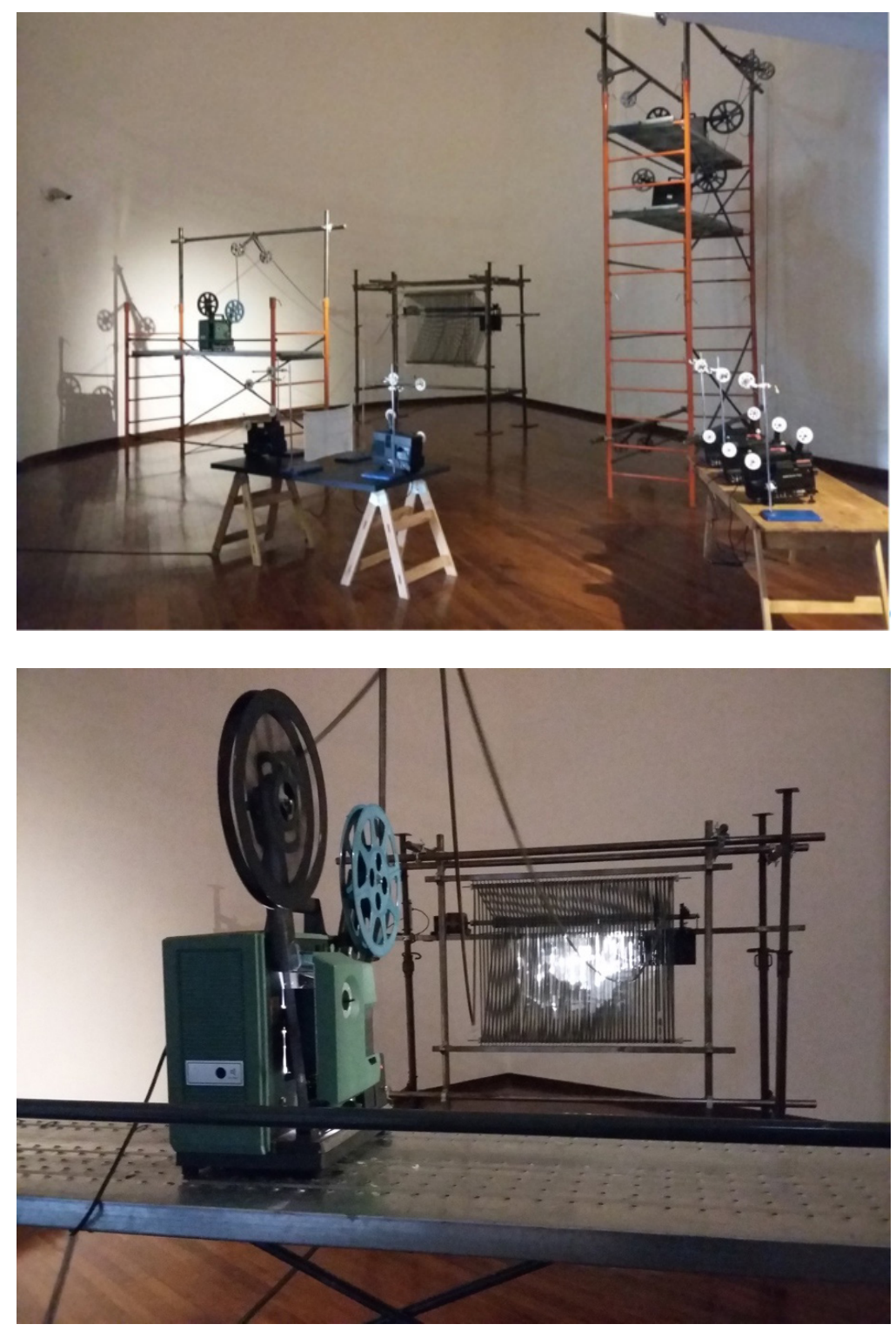

Fig 2. Andrés Denegri

Éramos Esperados. Plomo y palo, Aurora, Museo de Bellas Artes de Salta (2015) 
El artista argentino Andrés Denegri viene operando con el archivo fílmico, el metraje encontrado y la máquina original del cine los cuales sonexpuestos en el museo. Dos de sus muestras, Cine de Exposición. Instalaciones filmicas $^{7}$ (2013/14) y Aurora8 (2015) ofrecieron un relato sobre el cine, sus memorias como aparato y sus archivos. Los proyectores de cine, en sus diversos pasos de 35, 16 y S8 mm, se ponían en marcha a partir del paso de un espectador, quien a la par del celuloide se desplaza entre las máquinas de cine, sus haces de luz y las proyecciones resultantes. Ambas muestras situaban al cine en el centro de la escena del arte remitiendo a una historia de vínculos y rupturas entre el documental y el museo proponiendo una mirada retrospectiva sobre la práctica artística con los medios. La recuperación y manipulación del aparato cinematográfico y las imágenes del pasado culminaban en la proyección fílmica y en la exhibición de su maquinaria, bajo la forma de la instalación. El término de puesta en escena era revisitado pues remite al dispositivo $y$ al efecto cine operando en el espacio del arte para un espectador que deambulando por el cubo blanco del museo percibía imágenes, máquinas, haces de luz, sonidos y sombras de una fantasmagoría cinematográfica. El rol del espectador de cine había variado, de estar inmóvil en su butaca ahora necesitaba desplazamiento, despertando una percepción basada en el movimiento de su cuerpo y de los mismos archivos fílmicos que viajan por el espacio proponiendo una lectura de la historia del cine y su materialidad perdida y las maneras en que el archivo encontrado nos remite a la historia filmada, y proyectada. Podemos referirnos a un efecto cine fuera del cine, reformulado por la instalación en el espacio en la galería y el museo. Es emblemática la pieza instalativa Éramos esperados, Plomo y palo (2013) pues reformula esa visión de la historia en su memoria audiovisual, el frecuente capítulo de las imágenes de archovo de las represiones de las protestas populares y la defensa del orden establecido por el sistema de poder en Argentina es puesto en otra escena crítica. El recurso al 16mm no sólo opera en este caso como la medida del paso y del fotograma fílmico, sino que a su vez es la pelícua que hace de pantalla móvil, efímera y latente, de circulación de las imágenes. El sistema de su corrimiento excede la estructura material y narrativa del sinfín pues es la superficie donde se topa el haz de luz que lo atraviesa. En pocos metros de diferencia el fotograma leído por el haz de luz del proyector se convierte en la pantalla donde colisiona su propia imagen. De esta manera, la película es la superficie efímera que se proyecta en su trayecto de salida y retorno al proyector. El cine se proyecta sobre sí mismo, literalmente, las imágenes de represión policial y militar durante las movilizaciones obreras que se repiten a lo largo del tiempo como una constante histórica requiere un espectador atento y en movimiento. La obra reitera esa cadencia de orden y castigo, en la memoria y la materialidad misma del mecanismo de producción de las imágenes proyectadas que reiteran sin cesar la repetición de la acción y el paso

7 Cine de Exposición. Instalaciones filmicas de Andrés Denegri, curadoría Jorge La Ferla, Espacio de Arte de la Fundación OSDE, Buenos Aires, 2013.

8 Aurora. Instalaciones filmicas. Andrés Denegri, Museo de Bellas Artes de Salta, curaduría Andrea Elías y Jorge La Ferla, 2015. 
del tiempo. El haz de luz que se encuentra entre la imagen del fotograma original atravesado por la luz sobre el cual se proyecta la otra imagen. La máquina de imágenes se retroalimenta en la película convertida en pantalla, su percpeción requiere otra identificación crítica por parte del visitante.

Fig 3. Gerardo Suter, neoTrópico. Caja Negra y otros Microrelatos, Laboratorio Arte Alameda, Ciudad de México, (2017/2018).

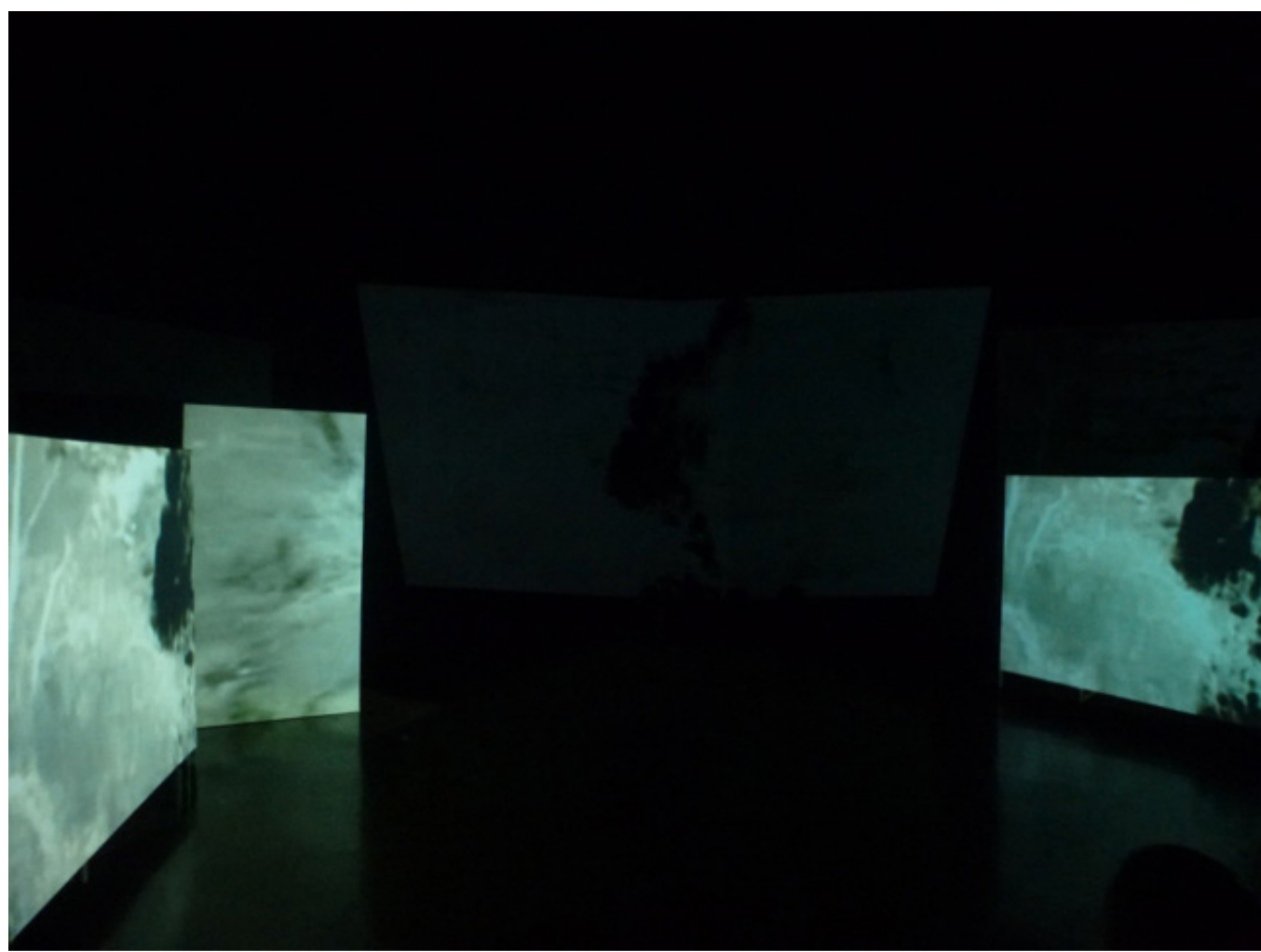

\section{Video Instalaciones}

El artista mexicano Gerardo Suter en su exposición neoTrópico. Caja Negra y otros Microrelatos, Laboratorio Arte Alameda, Ciudad de México, (2017) puso en escena el tema de las fronteras, los cruces clandestinos y el estatuto que implica ser otro a partir del cruce límites reales y simbólicos. Esta ambigüedad de un estatus que cambia al ser extranjero y que implica la persecución de un desplazado ya sea refugiado, inmigrante, o indocumentado. El neoTrópico de Gerardo Suter hace referencia a una región en apariencia cercana, como es el trópico, a partir de representaciones de su espacio físico, temporal, imaginario y mental. Estas inscripciones del conflicto entre locales y extranjeros provienen de una serie de textos sobre conquistas, incursiones, invasiones, apropiaciones, que tienen su fundamento en viajes, desplazamientos territoriales y en la condición humana. La aparente estética del viaje se convierte en un concepto que vincula los recorridos físicos por la naturaleza y la repre- 
sentación del otro - que ilusiona y enajena al viajante, al narrador, al artista, y en definitiva, al espectador urbano de la muestra. neoTrópico considera una memoria y un proceso histórico que hace a la condición del hombre en la relación con sus pares, donde la diversidad tribal, económica, nacional, ideológica, racial, va determinando diversas formas de representación de estas fronteras desde lo racional e ideológico a la conciencia alterada que construye el relato. Es el acto de contar, ilustrar, documentar a lo largo del tiempo que se inscribe en escrituras y lecturas a través de variadas materialidades tecnológicas, dispositivos y lenguajes en una memoria de archivos. La cordura del pensamiento y la locura creativa sugieren representaciones de traslados entre regiones -continentes, hemisferios, países- sorteando peligros en medio de una naturaleza exuberante que tergiversa cualquier idea de frontera. Sobrevivir a esos viajes implica un estado alterado de conciencia y de visión del mundo, inscriptos en el relato oral, el diario, el grabado, las crónicas, la ilustración, la fotografía, el cine, la imagen electrónica e informática, los cuales encuentran su forma combinatoria en la práctica de la instalación. La escena principal de neoTrópico es un espacio practicado donde el movimiento del espectador determina una percepción desde su mirada y tiempo en la obra. En la medida en que se desplaza el visitante, va cargando mentalmente la información sensorial que varía según el trayecto que elija. De esta forma, acompaña el deambular de los veinte personajes del video que se mueven por las imágenes fugadas sobre las paredes, las pantallas propiamente dichas, las sombras resultantes. Las imágenes proyectadas provenían de registros en night vision tomados por cámaras clandestinas de caza migrantes en la frontera de los Estados Unidos de las cuales no había mayores datos. El archivo estaba en cuestión, aunque ya no era el del prestigioso found footage fílmico, sino una imagen digital en movimiento subida anónimamente a las redes, la cual era procesada por Suter. Los personajes que en la noche caminan sigilosamente, se detienen, vuelven sobre sus pasos, dudan sobre la dirección, y retoman el movimiento, se asocian al diseño de lo que se espera del espectador de la obra. Así es como el espectador era otro clandestino el cual invade la obra, y en su experiencia de no saber hacia dónde va, tantea el espacio, escucha el entorno sonoro, observa su sombra, y por momentos se confunde con las siluetas de las proyecciones. Así, inmerso en cuerpo e instinto, el visitante iba generando una imagen mental que variaba según la persona. Era en la medida en que transcurría el tiempo que su conciencia interpretaba en el devenir de la imaginación que se disparaba por la desorientación y la pérdida de orientación inmerso en la obra. El espectador que invade la obra en su experiencia de no saber hacia dónde va, tantea el espacio, escucha el entorno sonoro, observa su sombra, y por momentos se confunde con las siluetas de las proyecciones, un pasante clandestino inmerso en el espacio convertido en un neo trópico. 
Fig 4. Jardín

Alameda, Gilbertto Prado y Grupo

Poéticas Digitales, Circuito Alameda, México, 2018

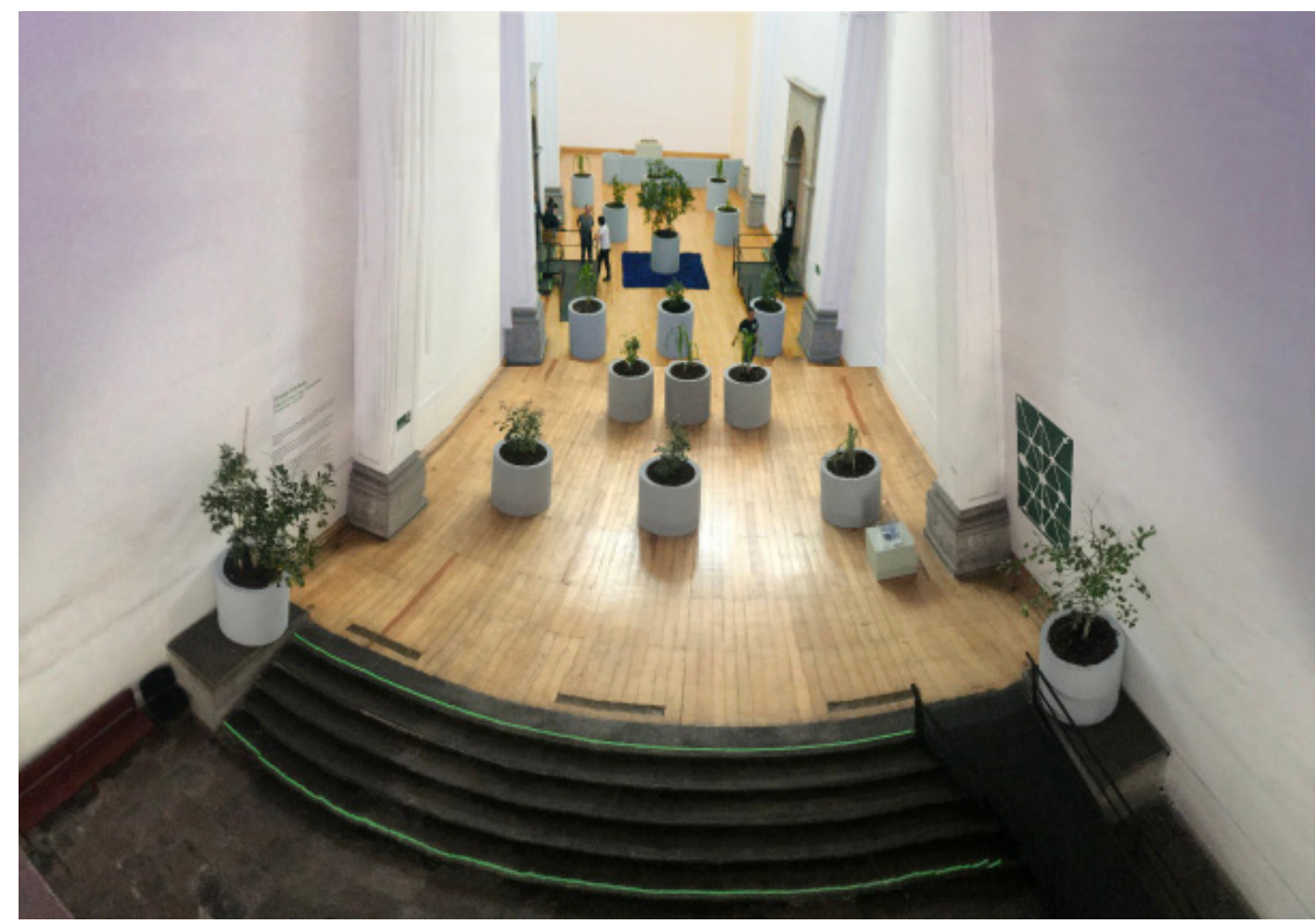

Circuitos urbanos.

En este mismo espacio emblemático de centro de la Ciudad de México, el Laboratorio de Arte Alameda, se presentó Circuito Alameda (2018) de Gilbertto Prado y del colectivo Poéticas Digitais de la Universidad de San Pablo de Brasil. La muestra contenía una serie de obras nuevas, así como un panorama de creaciones recientes, de uno de los artistas de referencia de las artes y los medios del continente. De larga trayectoria, la obra de Prado interviene sobre los medios de comunicación, el video, el bioarte y el arte interactivo así como piezas objetuales que van de la serigrafía al tapiz, entre otros. Otra serie de obras combinan objetos y medios analógicos con las nuevas tecnologías y parte de la propuesta expositiva era poner obra un panorama de más de tres décadas de la producción del artista. Por su parte las creaciones especialmente concebidas para la exposición establecieron un diálogo con el contexto mexicano y particularmente la Ciudad de México a partir del entorno espacial, temporal e histórico del Laboratorio Arte Alameda. Así es como la muestra puso en escena la locación y la arquitectura del Laboratorio que funciona en el antiguo Convento de San Diego (1594) y la vecina Alameda Central en el centro de México buscando rememorar trayectos entre un interior vinculado al claustro religioso con el parque exterior con sus senderos, especies botánicas y el agua de sus fuentes. Así fue como se diseñaron un conjunto de piezas que pusieron en obra especies de árboles y plantas en torno al agua como alegoría de la historia de la Ala- 
meda. Las plantas de las obras de Jardín Alameda y los frutos locales de Caja de choque, maíces, chiles y naranjas, se presentaban en tanto objetos de la naturaleza locales, los cuales fueron dispuestos y conectados entre sí, generando diversos flujos de energía que recordaban en parte las instalaciones de Víctor Grippo.

Fig 5. Caja de Choque, Gilbertto Prado y Grupo Poéticas Digitales, Circuito Alameda, Capilla de Dolores, Laboratorio Alameda México, 2018.
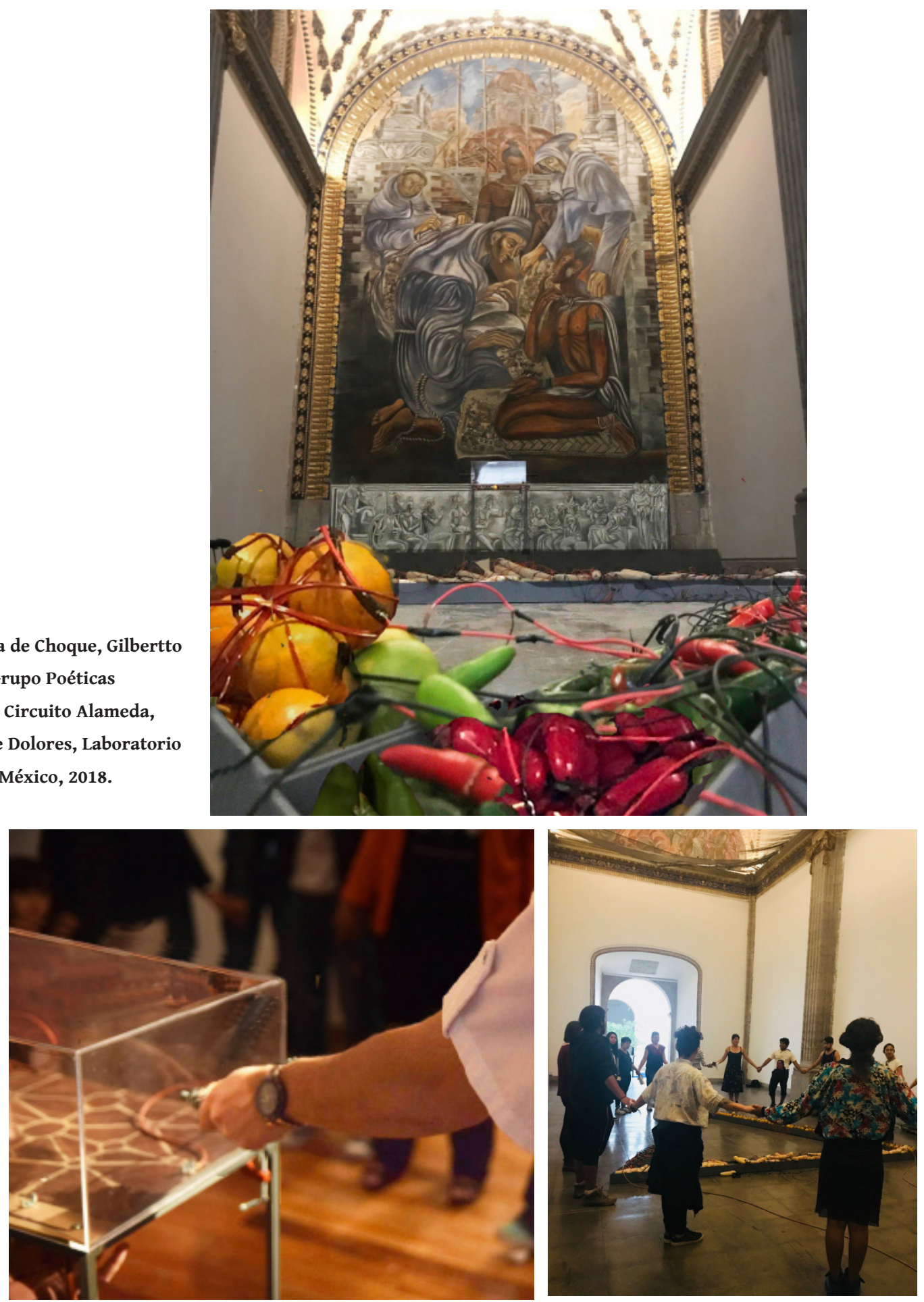

DATJournal v.6 n.4 2021 
La Caja de Choque, fue otra pieza clave site specific, cuya imponente estructura metálica triangular, contenía pimientos, maíces y naranjas, conectados entre sí por cables, generando la energía que culminaba en una estructura de acrílico con dos manillas. Una obra que remitía a los Toqueros y sus cajas de toques, un fenómeno tradicional en las noches del centro histórico de la Ciudad de México. Estos aparatos son, en el refrán popular, utilizados para aliviar el stress y la embriaguez - o probar la valentía - a través de los cuales las personas se auto-inflingen corrientes eléctricas. La caja de acrílico transparente traía el circuito de la Plaza Alameda impreso en la placa electrónica la cual era alimentado por la energía de los frutos inter conectados. Los elementos, impregnados de historia y cultura, se propusieron asociados para recordar los encuentros culturales a partir de los procesos de la colonización. Al fondo de la capilla de las Almas, en diálogo con la Caja de choque se imponía el fresco "Los informantes de Sahagún", de Federico Cantú, que representa el encuentro de los indígenas con los evangelizadores.

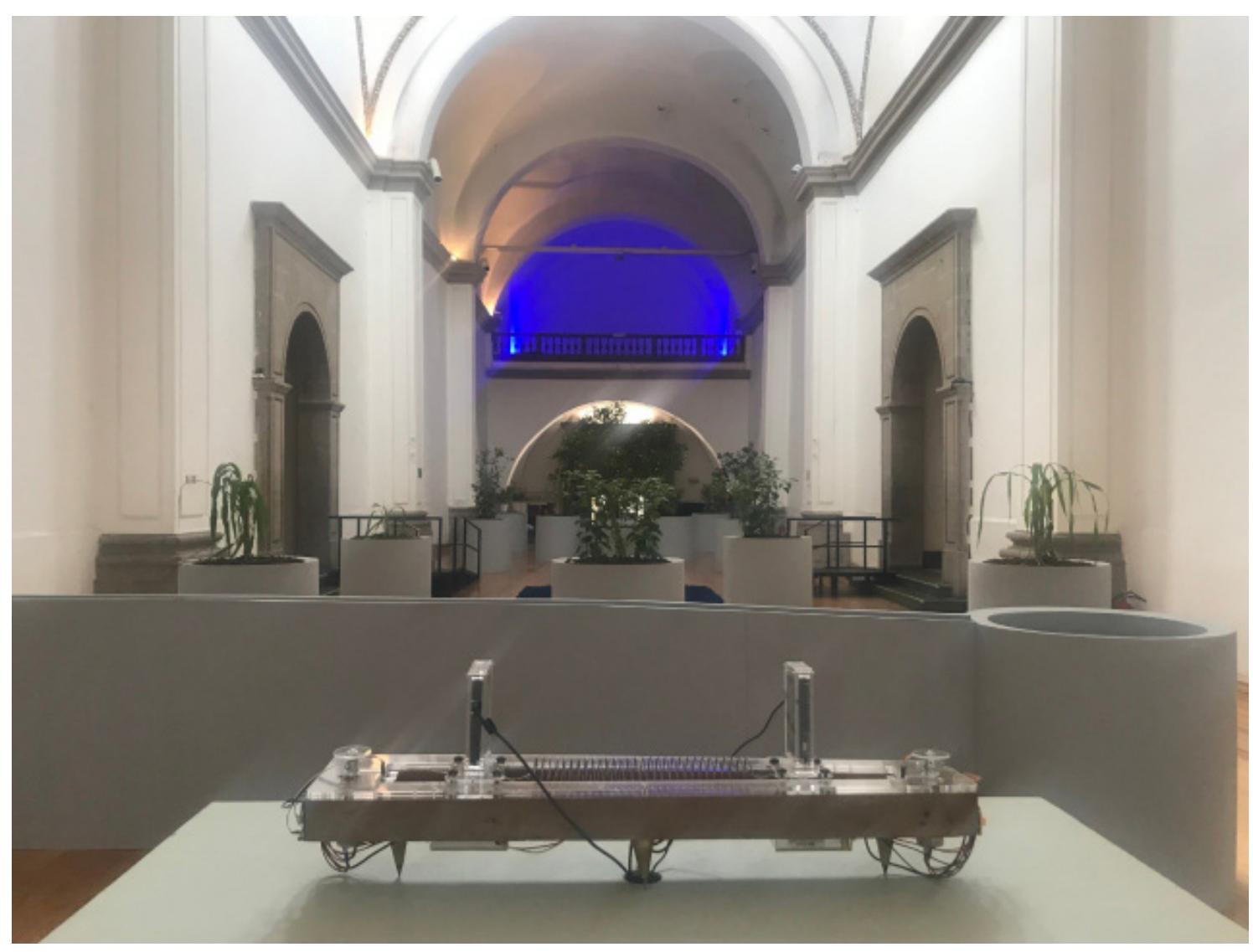

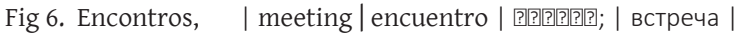
प to Prado y Grupo Poéticas Digitales, Circuito Alameda, Laboratorio Alameda México, 2018. Foto: Gilbertto Prado. 
Como parte de la serie de la muestra compuesta por piezas antológicas de Gilbertto Prado, Encuentros, es parte de una alegoría de la representación del agua para una obra que se presenta sobre una base de madera tallada de un árbol de la región amazónica. La combinatoria de los elementos mecánicos y objetuales sostienen los dos aparatos móviles encendidos que reciben información en tiempo real. Ambas pantallas están enfrentadas sobre la plataforma siendo sostenidos sobre una guía y resortes, que los aleja y acerca. La madera, losaparatos, los materiales de metal hacen de la pieza una escultura híbrida, elementos diversos que están en la base del pensamiento poético de Prado. El permanente movimiento de la pieza está asociado a las imágenes de las aguas de las pantallas. Este vaivén de los móviles responde al procesamiento de datos provenientes de las redes. Por un lado vinculado al registro de las fases lunares, su vinculo con las mareas, y con el cauce y cruce entre las aguas de dos vertientes del río Amazonas. Asimismo hay un juego semántico con las variables tipográficas alrededor del término encuentro en sus diversas acepciones idiomáticas, los resultados obtenidos de su búsqueda en la red determinan la cadencia del movimiento de los móviles y sus imágenes. La palabra encuentro remite a un movimiento de aproximación y lejanía, encuentro y separación, espacial y geográficos. Es el resorte que aproxima los móviles el que ofrece la resistencia mecánica que a su vez, los aleja impidiendo su contacto físico. Encuentros es una pieza que sintetiza en sumaterialidad y funcionamiento, la combinatoria de elementos naturales con aparatos de comunicación, en su vinculo con las redes informáticas.

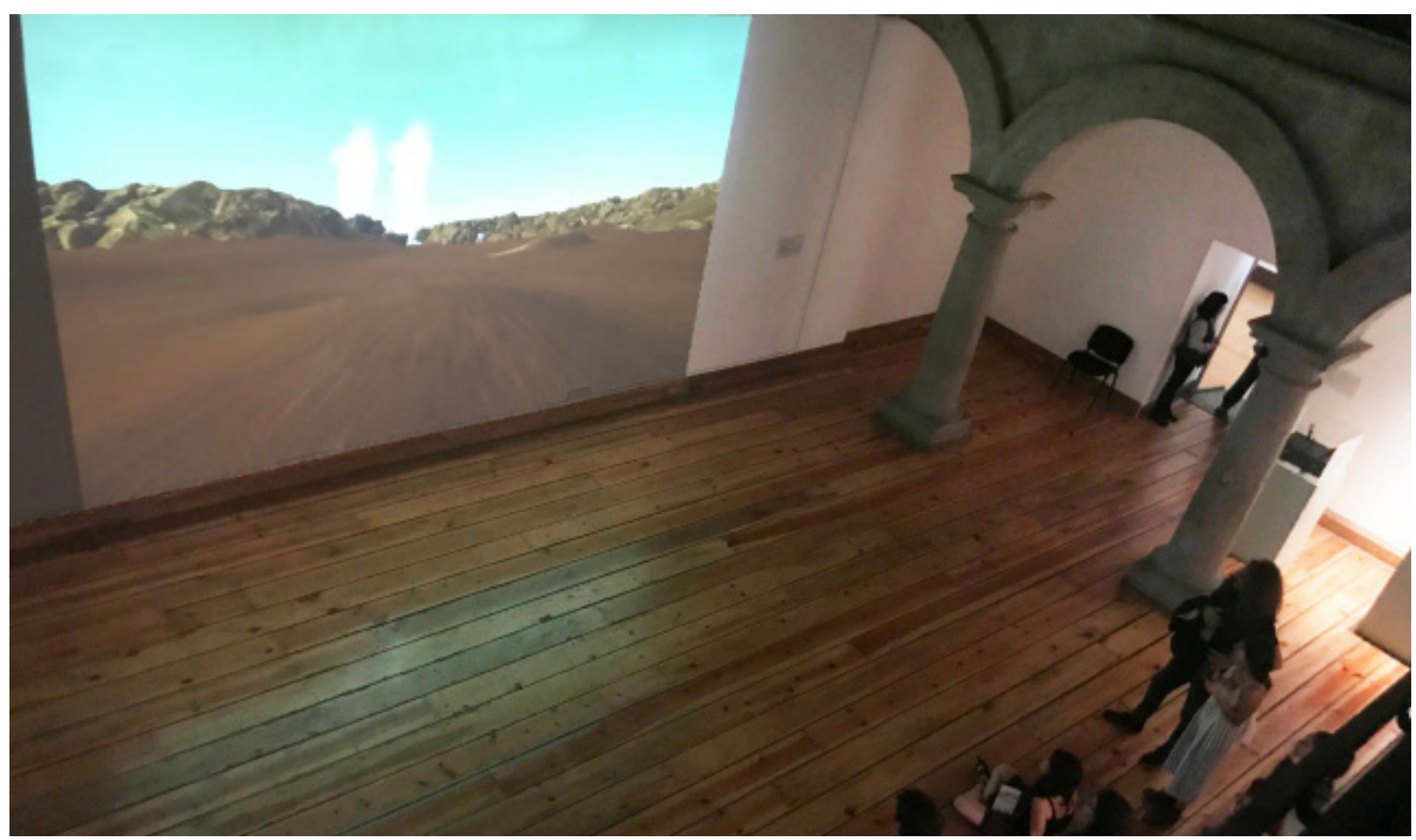

Fig 7. Desertesejo (2000/2014),

Gilbertto Prado, Laboratorio

Alameda México, 2018 
Fig 8. José Alejandro Restrepo, Materiales para la Misión en China (2017). Religión Catódica, Espacio de Arte de la Fundación OSDE, Buenos Aires.
Estas memorias sobre la obra de Prado, entre las cuales estuvo la nueva versión de Desertesejo (2000/2014) obra multimedia de realidad virtual cuya vigencia es testimonio de la problemática del acervo de obras tecnológicas para un proyecto de referencia en la historia de las artes mediáticas del continente. Desertesejo en sus versiones a lo largo de dos décadas conforma una meta data que sortea el síndrome del arte digital como es su rápida obsolencia que caracteriza las obras interactivas en su hardware, programa operativo, interface, agenciamientos expográficos y repositorio archivístico. Esta muestra desplegada en más de 600 metros cuadrados estuvo compuesta por diagramas, serigrafías, espacios lúdicos virtuales, plataformas interactivas, pantallas móviles y variados objetos. Un conjunto articulado bajo la forma de instalaciones sonoras y objetuales, piezas autogenerativas e interactivas de telepresencia, jardines y plantas. El recorrido de cada visitante por la exposición determinaba un circuito propio el cual era registrado, y luego cartografiado, a través de sensores y traqueos, que resultaban en una proyección de su circuito personal a la salida de la exposición. Un circuito personal que representaba la performance de cada visitante por el espacio de la exposición que resultaba en un gráfico híbrido a partir de las líneas imaginarias que conectaban las diversas obras de la muestra. Circuito Alameda continuó el extenso proceso de investigación, producción, montaje y documentación de una memoria de obra de tres décadas de creación de Gilbertto Prado con las artes y los medios.

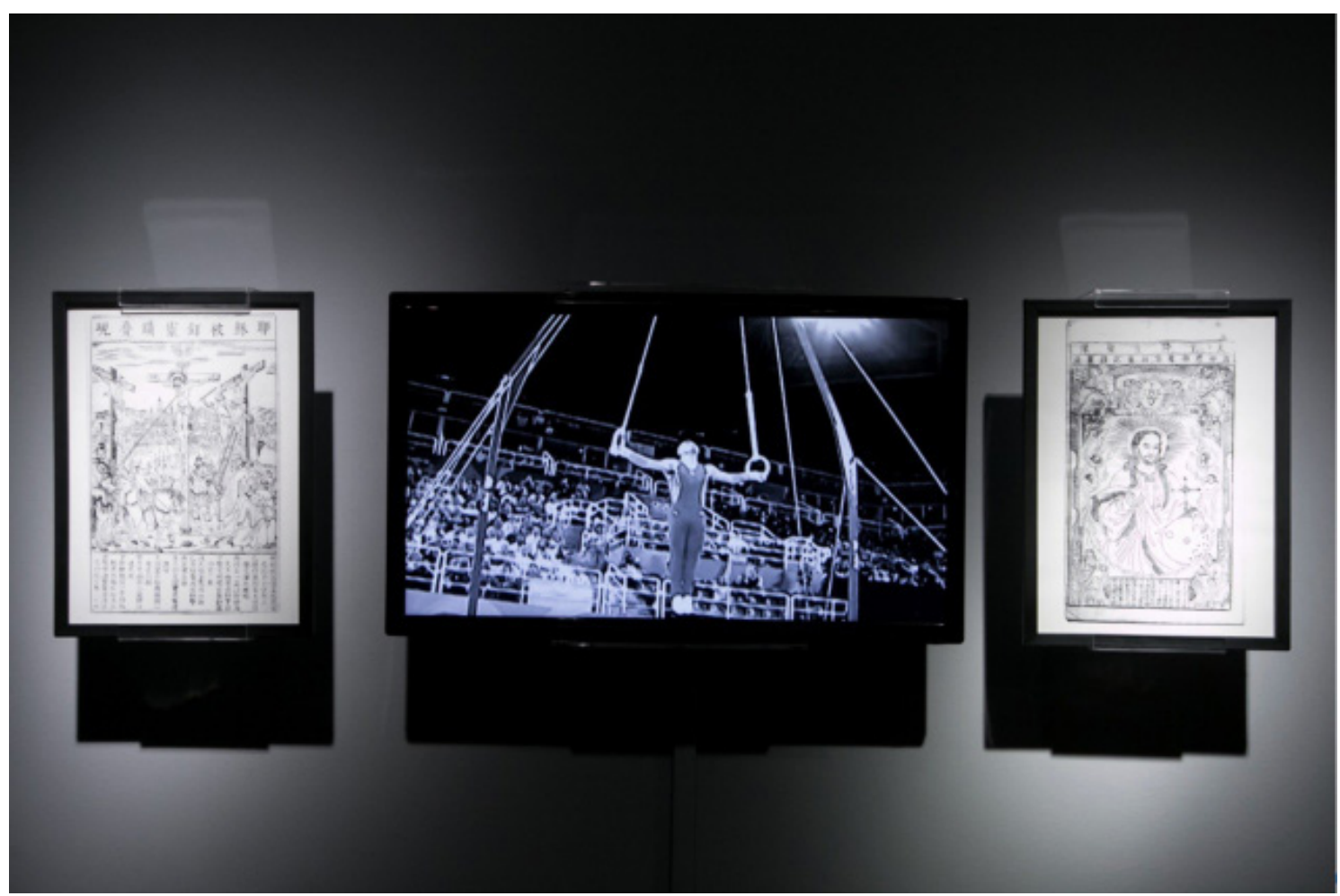


Religiones Catódicas. José Alejandro Restrepo, ha llevado hasta el paroxismo una visión crítica de Colombia y de la región, a partir de una extensa obra compuesta por performances, objetos varios, serigrafías, grabados, fotografías, objetos entre los cuales editoriales, y piezas biológicas, video, instalaciones. La muestra en Buenos Aires, Religión Catódica (2017) resumió parte de estos derroteros al confrontar escritos e imágenes de la historia, relatos y recorridos por el discurso de la ciencia y la religión combinados con mitos indígenas, el saber popular y los vestigios de narraciones provenientes de diversas partes de Colombia. Inscripciones para un relato crítico cuestionador del discurso de los aparatos ideológicos del estado asentados en los manuales escolares, los cantos patrios, los evangelios y particularmente los medios masivos de comunicación. Religión Catódica puso en escena un amplio panorama de la obra de Restrepo basado en investigaciones sobre las elocuciones conforman la arenga, la encíclica, el manifiesto los bandos militares. Las invocaciones divinas, que promovían la evangelización del otro - es decir, el enemigo, el extraño, lo diferente, lo divergente, eran desarmadas por Restrepo. La reminiscencia de imágenes del pasado y los textos de los medios masivos de comunicación funcionan como una base de datos manifiesta mediante diversas formas y dispositivos. Las imágenes tecnológicas en cuestión procedían de un arte de la memoria sobre un país a partir de la crítica al poder dominante, que se expresa a través de la política, la religión y la educación y sus instituciones. Pero también se destacaban las manifestaciones de un imaginario popular divergente a ese discurso dogmático. Restrepo propone acciones concentradas en la representación del cuerpo humano y la figura divina a partir del uso de la tecnología desde la apropiación y manejo del archivo.

Así es como esta exposición surgía de una práctica artística que dialogaba con la imagen documental. Algunas de las obras contenían la imagen de video que según el caso era combinaba con otros soportes pictóricos, fotográficos e informáticos y escenográficos. Por ejemplo, la nueva obra inaugurada en Buenos Aires, Materiales para Misión en China (2017) consistía de un tríptico compuesto por dos grabados y un video. Las históricas ilustraciones de Evangelicae Historiae Imagines (1537) de Jerónimo Nadal que provenían de las versiones de Giulio Aleni (1637) quien concibió una edición que fue adaptada para las misiones evangelizadoras en China. Este es un tema mayor, pues se vincula con una historia de la representación, de textos e imágenes, que desarrolla la Iglesia a partir de la práctica religiosa de referencia instaurada por San Ignacio de Loyola, cuya influencia se mantiene durante siglos. Creer en Dios se deriva de la fe en los textos y las imágenes técnicas. 
Fig 9. José Alejandro

Restrepo, Variaciones sobre el purgatorio N. 1 (2017). Espacio de Arte de la Fundación OSDE. Foto: Estudio Ledesma Hueyo

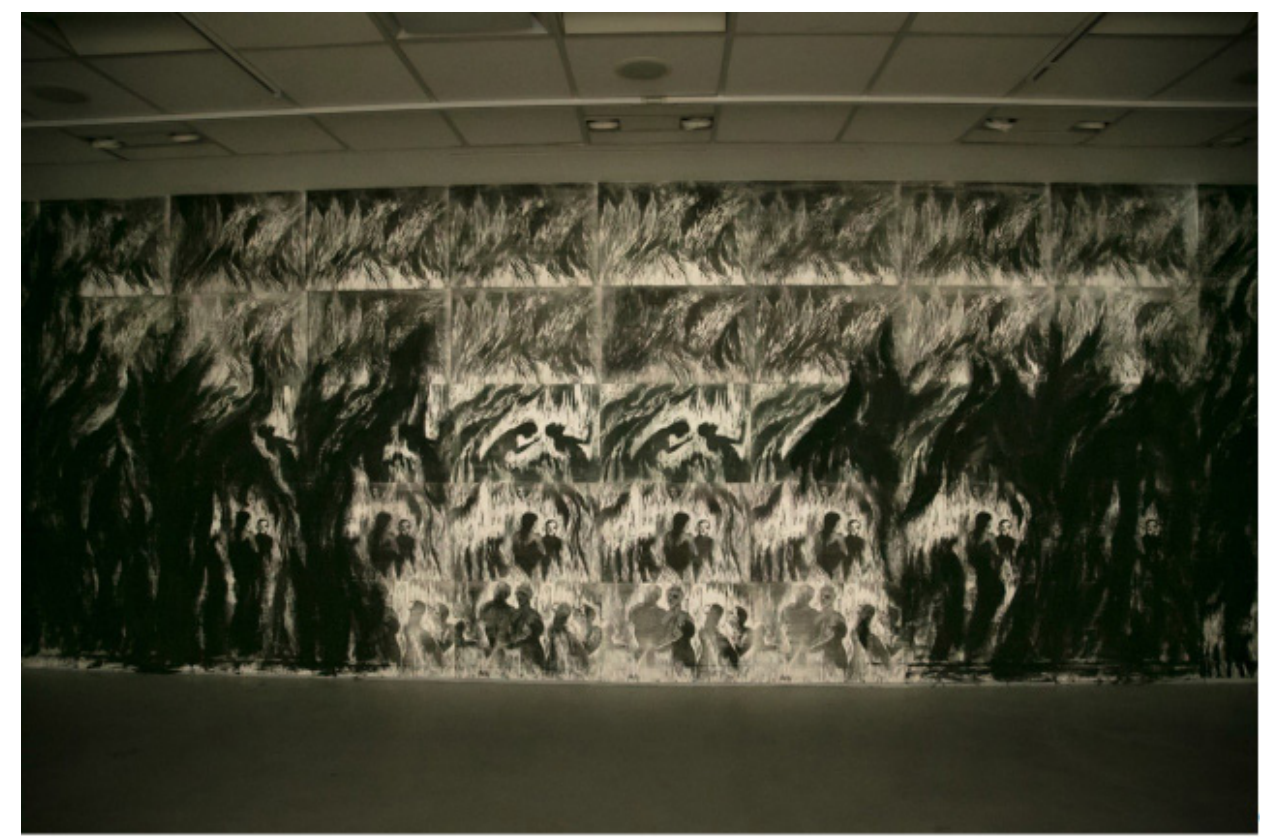

Estas lecturas de los textos religiosos vinculados a la evangelización se continuaba con la serie Variaciones sobre el Purgatorio (2017) cuya versión de Buenos Aires fue concebida para una sala cerrada con un fondo cubierto por grabados. Este escenario empapelado con papel afiche de una misma imagen se complementaba con una proyección en video con la misma imagen, trabajada digitalmente, con variados efectos de luces y sombras que provocaban un efecto alucinatorio. Una obra que se consumaba con el espectador observando en la escena. Este locus espacial y temporal remitía a un limbo teatral, donde se combinaban una vez más las dos tramas referidas de Restrepo, el grabado y la imagen de video, con el espectador completando la acción con su cuerpo y su mirada en una escena ominosa del purgatorio.

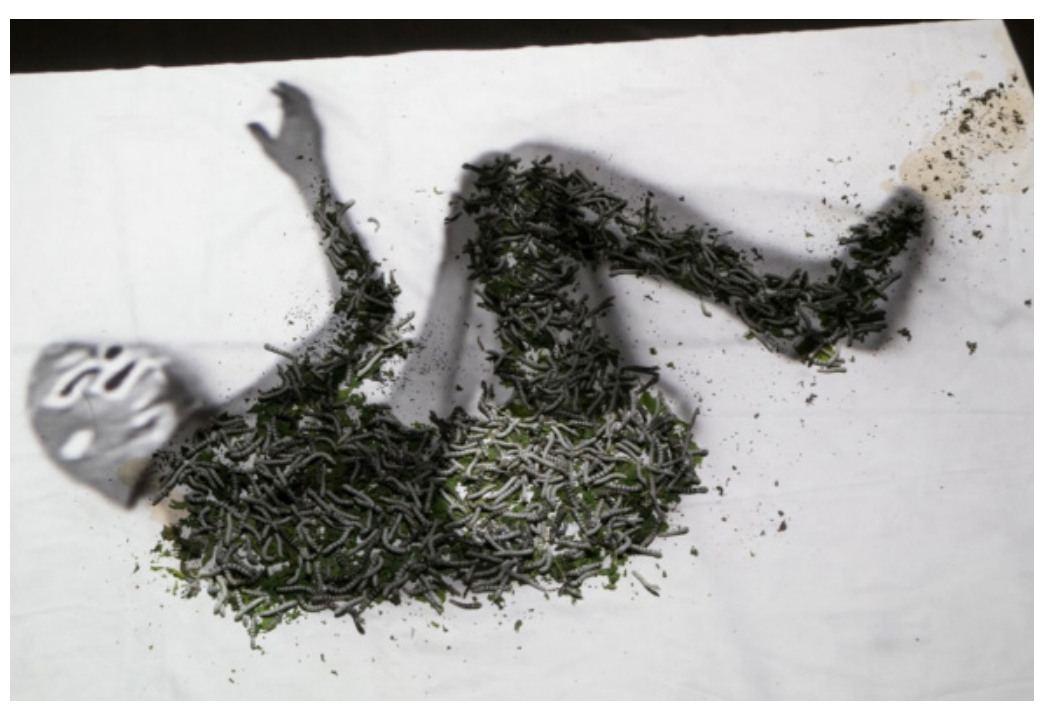

Fig 10. José A. Restrepo, Santo Job (2017), Espacio de Arte Fundación OSDE. Foto: Estudio Ledesma Hueyo 
Santo Job (2017) por su parte, combinaba una proyección de video con objetos con gusanos de seda criados para la ocasión. El haz de luz cenital desde un proyector de corto alcance y su lente gran angular, se vuelve imagen en una sábana blanca que est. Sobre el piso. El esmirriado cuerpo del personaje de la imagen que yace acostado contrasta con su máscara de El Santo, el héroe de la lucha libre mexicana. Pero en este Santo Job, la fragilidad del personaje inerte contrasta con el antifaz del mediático y poderoso justiciero. Los gusanos de seda sobre la proyección del cuerpo se convierten en capullos y luego en mariposas. Santo Job rememoró la legendaria pieza de Restrepo, Musa Paradisíaca (1996) compuesta por plantas de banano cuyos tallos culminaban en pequeños monitores de video blanco y negro con imágenes de la región de Urabá, en momentos en que latifundistas del banano generan situaciones de violencia para expulsar a los campesinos de sus tierras. A lo largo del tiempo de su exposición se van degradando a la par que la situación en esta región de Colombia. Restrepo cuestiona con estas obras la banalidad del género, politizando el bioarte de manera certera. Podemos considerar a Restrepo un comentador privilegiado que procesa la realidad colombiana y, por extensión, latinoamericana, a través de formas de representación que se concentran en el uso del archivo puesto obra en la práctica híbrida de la instalación. En esta línea de pensamiento expositivo de la imagen en movimiento, Santo Job se constituyó en un nuevo capítulo al complejizarse el dispositivo y los elementos que componen la pieza que se formula en la combinatoria de arte, tecnología y biología. La muestra Religión Catódica ponía ejercía un arte de la memoria crítico del poder dominante en sus diversas expresiones. El cuerpo humano y la figura divina se manifestaban a partir de la manipulación de los diversos archivos que dialogan con la imagen documental y una propuesta desbordante alrededor de la representación del discurso de la historia, la religión y la resiliencia de una población que se afirma en sus creencias que difieren de la imagen de los medios masivos.

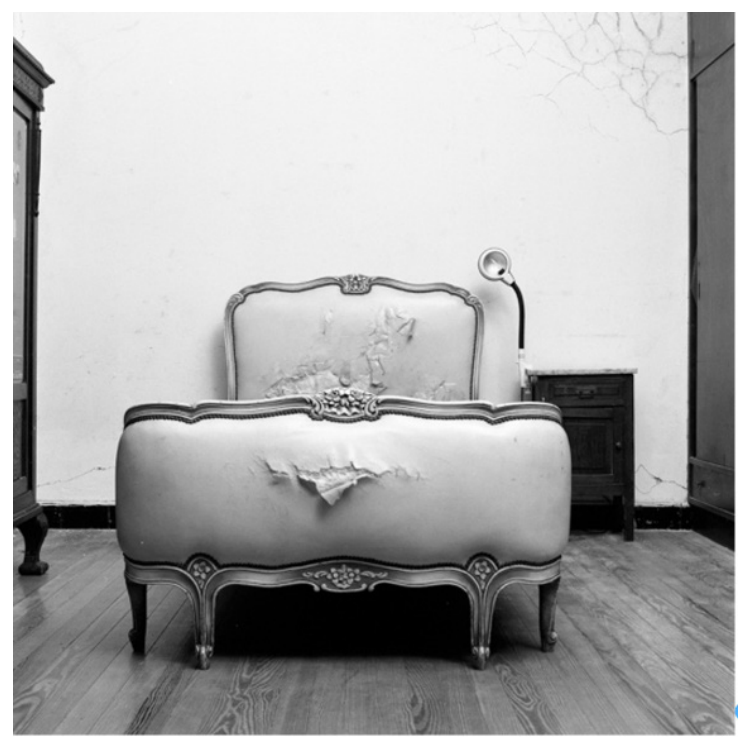

Fig 11. Intermitencias,

Irina Raffo, (2019/2022) 
La fotógrafa y realizadora uruguaya Irina Raffo viene trabajando hace varios años en su primera exposición personal, un proyecto que comprende textos, referencias, textuales, visuales y sonoras. Esta bitácora de apuntes de bocetos y reseñas consiste en un proceso de escritura el cuál reviste un carácter ensayístico pues reflexiona sobre la misma acción proyectual. En esta muestra individual la artista traza un relato de la memoria personal bajo la modalidad de un autorretrato. Intermitencias (2019/2022) es un proyectual resultado de una senda investigación sobre la historia de su familia, cuyos vestigios convergen en la introspección de la propia artista. Este proceso de puesta en obra del "yo" interpela una genealogía personal asociada a una serie de piezas y objetos mediáticos que confluyen y dialogan entre sí, en el espacio de la instalación.
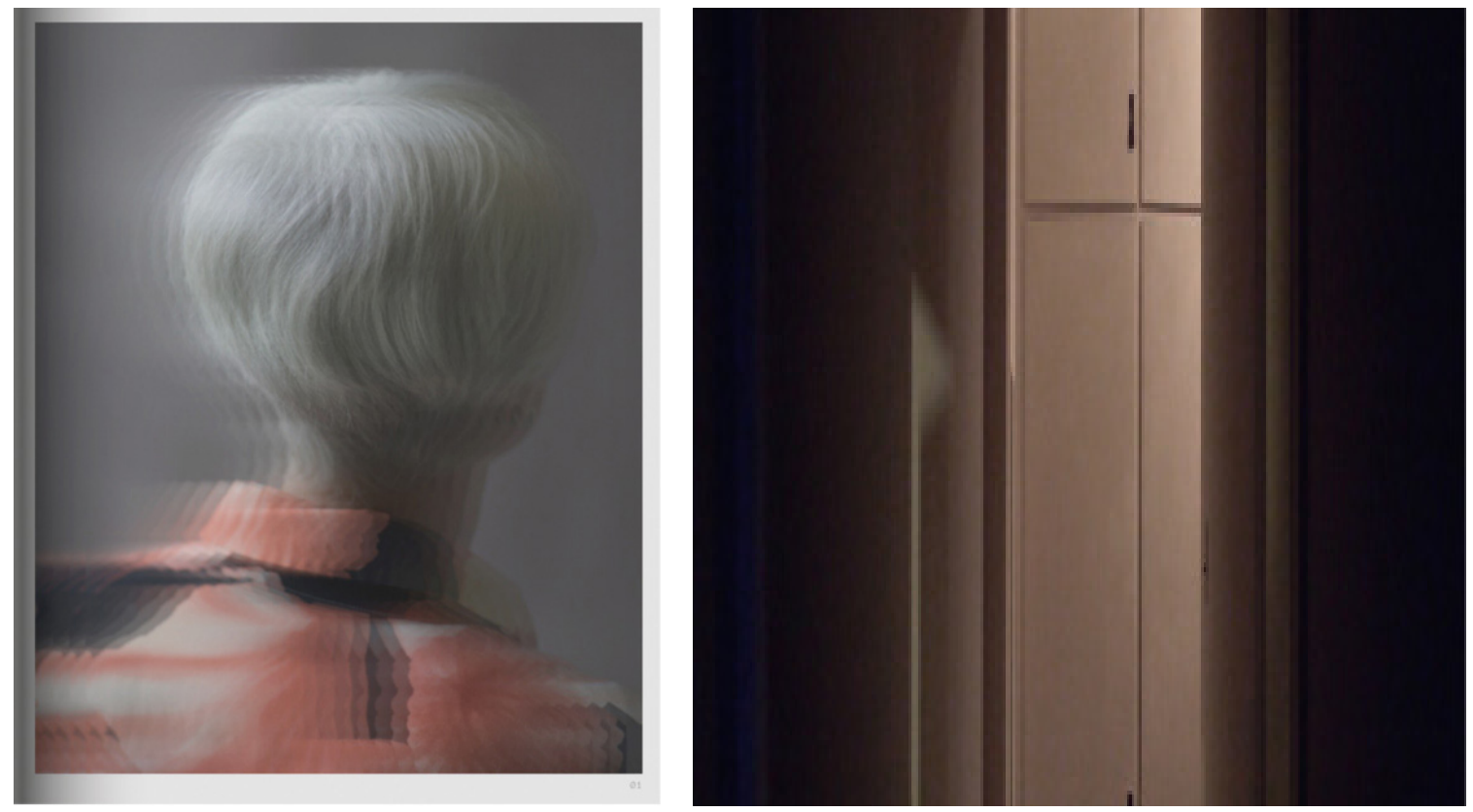

Fig 12. La otra Eva (2020) Fotografía multicapas. Captura e Impresión digital Eva por Irina (2017) Corto documental, 15 minutos. Proyección Full HD.
Es lo fotográfico una de las vertientes que operar la reminiscencia de personas y tiempos pasados, entre las cuales se encuentra Eva -la abuela de Irina-, protagonista emblemática de este arte de la memoria de la realizadora cuya huella se inscribe en la materialidad de las sales de plata de la fotografía analógica de lo que fue su cama. Sigue la serie de imágenes expandidas que van de un efecto de realismo armando una narrativa de (no) ficción que va de la materialidad fotoquímica a los soportes digitales, las cuales se despliegan en la galería de arte como tablas mágicas suspendidas en el aire, ya sea como proyecciones u objetos colgados de las paredes. Las íconos de los espacios familiares son puestos en abismo, la acción de su captura de origen del pasado son exhibidos en la sala a través de un fantasmagórico juego de espejismos. En estas imágenes aquellos seres queridos y los interiores que habitaban brillan por su ausencia pues ya no hay quien los habite; sin embargo 
Fig 13. Mamá Golem (2017) Proyeccion Full HD + audio de dos canales Adaptación para CCE de pieza performática presentada en la UTDT. ocupan un lugar en la memoria de la artista y en sus invenciones. Así es como Intermitencias se articula en soportes analógicos y numéricos, proyecciones monocanales, instalaciones. Los pasajes de las imágenes fijas a (la ilusión de) las imágenes en movimiento, culminan con la videoinstalación Un gesto de memoria circular (2019), una obra que evidencia esta combinación de materialidades y dispositivos (audio)visuales concebidos para las salas expositivas del emblemático Centro Cultural de España en Montevideo. Además de fotógrafa, Raffo es realizadora de cine y video que van del corto al largometraje de ficción siendo la vertiente documental la que predomina en sus piezas instalativas, algunas de las cuales se (re)convierten en videos monocanales los cuales son proyectados en la muestra.

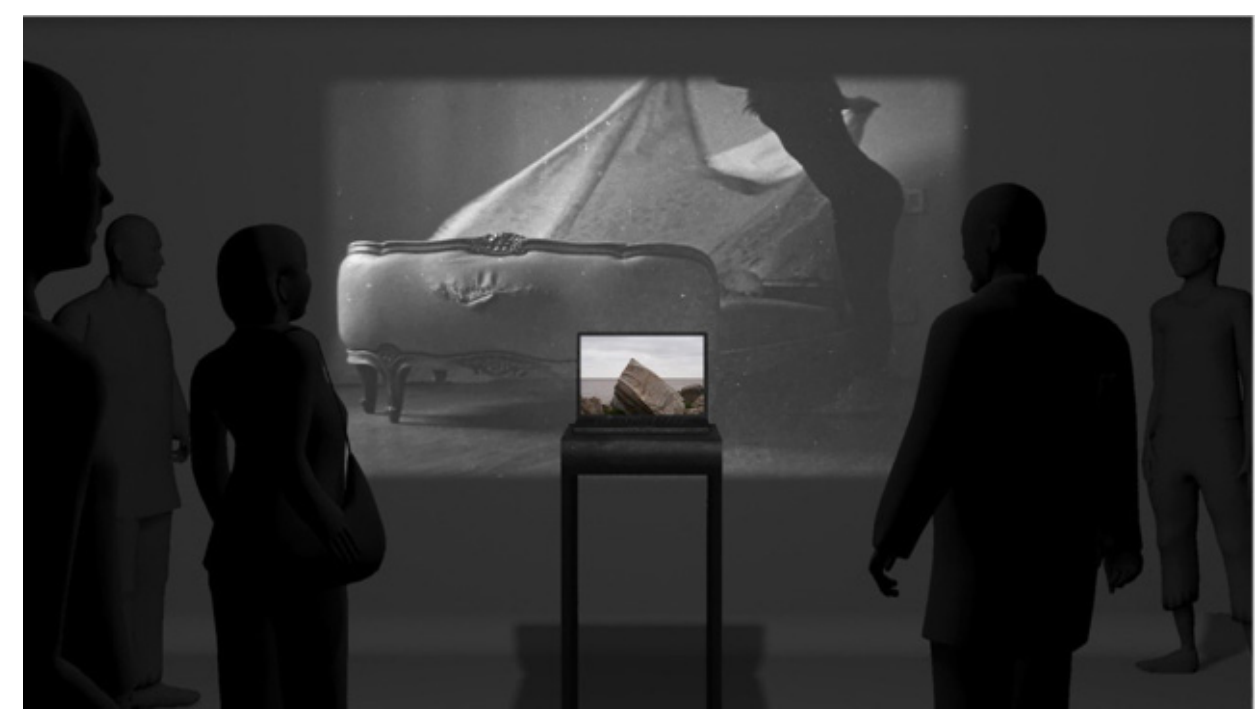

Fig 14. Intermitencias: ensayo sobre una película posible (2018) Documental instalativo. Proyeccion full HD + monitor LCD de 50 pulgadas.

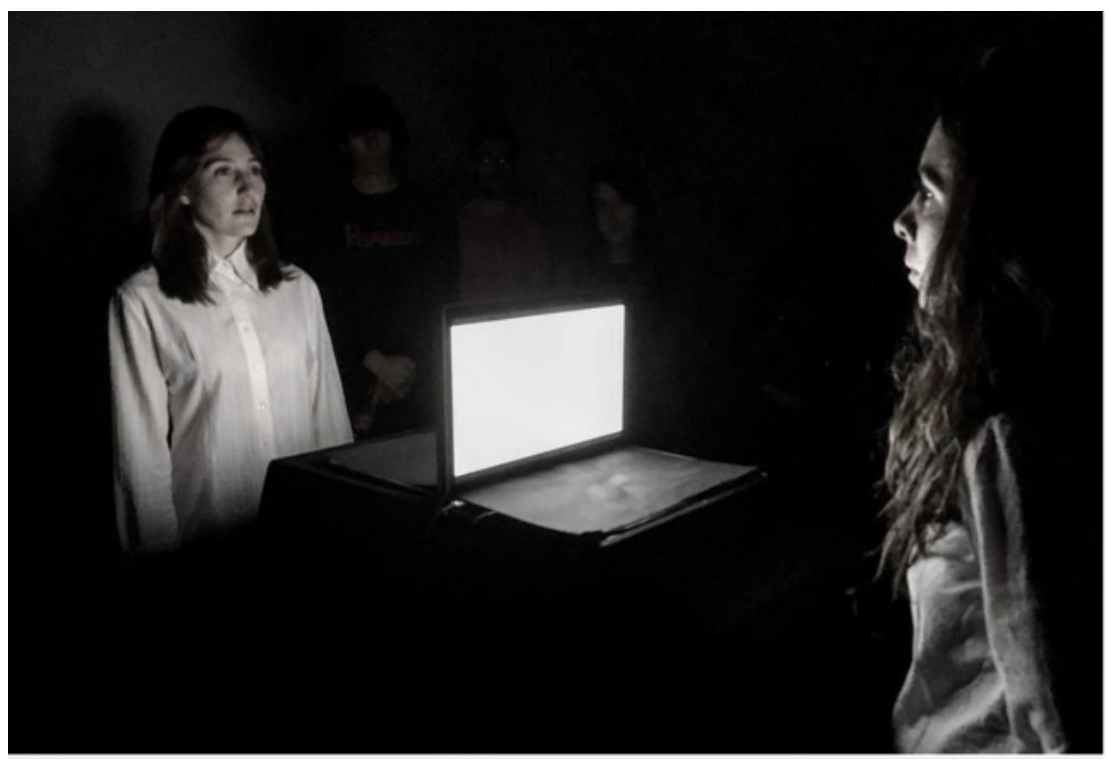


Tal es el caso de Mamá Golem (2017), que rememora el diálogo performativo entre las descendientes de la abuela Eva es decir su hija, la madre de la artista con su hija, es decir la artista. Una pieza cuyo dispositivo original -dos ordenadores enfrentados en su reverso reproducen las imágenes de madre e hija, entre las cuales circula el cuerpo del espectador- se convierte en Intermitencias en una pieza monocanal multilayered donde las facciones de ambas mujeres convergen en una sola imagen resultado de sus sobreimpresiones. Esta versión de Mamá Golem mantiene la prueba indicial del efecto face to face de la recordada instalación performática, en la que se confrontan ideas y gestos de la intensa línea filial materna. el cortometraje Eva por Irina (2017), por su parte, deja de lado lo anecdótico para relevar con elocuencia el sonido directo del video digital resalta como la obra más emblemática de estos intercambios entre abuela y nieta. El cortometraje documental La tormenta es lo que llamamos progreso (2019) es otro notable ejemplo en el que la imagen implica una búsqueda -imposible, por cierto-de locaciones reales, aunque dudosas en su función de memoriales si tenemos en consideración la trágica historia europea de mediados del Siglo XX y la manera en que el mercado del turismo usufructúa a través de los famosos city tours. Este derrotero, se continúa con Intermitencias: ensayo sobre una película posible (2028), un documental instalativo que intenta reconstruir la historia familiar y comprender las extrañas formas del recuerdo. Su puesta en obra concentra el efecto combinatorio en su proyección a gran escala junto a un ordenador portátil -ubicado frente a la proyección-que reproduce las huellas y referencias fílmicas de lo que vemos en pantalla grande. Este recurso genera una sensación similar a la del picture in picture, donde las imágenes del ordenador se superponen como un pequeño recuadro sobre las imágenes proyectadas. Dichas variaciones en torno a la imagen documental, de archivos propios y ajenos, montados y desmontados, son estrategias elaboradas por la propia artista que renuevan la lectura de sus obras pasadas, expuestas bajo otros sistemas de exhibición. Se conforma de esta manera un autorretrato para un espectador que debe recomponerlo fragmentariamente a partir de su recorrido por la muestra, según el movimiento de su cuerpo y mirada. Raffo expone en su modus operandi un perfil de artista multimedia que se apropia de las técnicas audiovisuales para generar piezas fotográficas, cortometrajes, films de ficción y documental. Raffo además interviene en los dispositivos de exhibición de sus obras, que van de la proyección monocanal en la sala a oscuras para propuestas concebidas para el ámbito del arte contemporáneo. Todo un discurso sobre la cuestión documental que se expande en una pieza editorial, bajo la forma de libro de artista. Irina Raffo representa un peculiar modelo de artista que opera de manera experimental con las máquinas de imágenes a través de una acción creativa que va del cine al video, de la instalación al libro de artista, a partir de los cuales reconstruye memorias desde un entorno presente con las reminiscencias de un pasado puesto en obra en el campo de arte contemporáneo. 


\section{Memoriales}

Esta bitácora de obras y autores de América Latina evidencian una práctica que involucra los variados campos de la producción artística, la academia y el museo contemporáneo. En todos los casos es el diseño del proyectual de cada exposición el que va trazando un guion con mucho tiempo previo a su montaje en sala. A nivel personal estos procesos implicaron reconsiderar instancias de curaduría muy diversas a la programación de muestras de obras monocanales para ser proyectadas en el ámbito de la sala oscura. Estas memorias hacen a un work in progress pensado para concretarse en el campo expositivo que surge de las etapas proyectuales a las exposiciones en sí. Esta memoria compilatoria revisitando estas muestras de manera transversal intentando delucidar temas y problemáticas en común a partir de su diseño y las maneras de ponerlos en obra donde que predomina la práctica de la instalación. Si bien el aislamiento y las restricciones impuestas por la situación sanitaria han condicionado las instancias expositivas en los espacios de arte sigue vigente la cuestión de los vestigios de las muestras temporales que son efímeras quedando parte de su memoria en los proyectuales y la documentación que surge de su tiempo de montaje y exposición.

Son pocas las obras y los artistas que consiguen articular un discurso coherente y profundo sobre lo que puede implicar representar cuestiones centrales que hacen a nuestra región. La dictadura militar y el pasado violento de las luchas sociales en el siglo XX en Argentina; la historia de la conquista, la inquisición, las civilizaciones originales y el diseño urbano de la ciudad de México; la religiosidad y el culto a los medios como lectura del conflicto en Colombia; la inmigración clandestina en los nuevos trópicos; recorrer instancias de vida de los antepasados en sus periplos entre Europa y el Río de la Plata como forma de autorretrato remiten todos a lecturas crítica del continente a través de la práctica de la instalación de arte mediático. Este conjunto que conforman las referidas muestras de Albertina Carri, Andrés Denegri, Gilbertto Prado, Irina Raffo, José Alejandro Restrepo y Gerardo Suter ofrecen un discurso elocuente sobre memorias personales, relatos sobre la historia y visiones de un presente siempre en crisis los cuales ofrecen incisivas lecturas sobre el continente y sobre las maneras de ponerlos en obra en los espacios de arte contemporáneo.

\section{Referencias bibliográficas}

Carri, A. (2015). Operación Fracaso y el Sonido Recobrado, Parque de la Memoria, Buenos Aires, Buenos Aires. https://parquedelamemoria.org.ar/wp-content/uploads/2020/04/AlbertinaCarri_PDM2020.pdf

La Ferla, J., García, C. y Arancibia, V. (2015). Aurora. Instalaciones fílmicas. Andrés Denegri. Salta: Museo de Bellas Artes de Salta. Recuperado de: https://issuu.com/basalta/docs/aurora_catalogo (Consultado el 1.12.2021) 
La Ferla. J. (2013). Cine de Exposición. Instalaciones fílmicas de Andrés Denegri. Buenos Aires: Espacio de Arte Fundación OSDE. http://www.historicoartefundacionosde.com.ar/backend/upload/files/img_\$272.pdf (Consultado el 1.12.2021)

Machado, A. (2007). El paisaje mediático. Buenos Aires: Nueva Librería.

Mello, C. Extremidades. www.extremidades.art (Consultado el 1.12.2021)

Prado, G. y La Ferla, J. (2018). Circuito Alameda. Ciudad de México: Laboratorio Arte Alameda, Instituto Nacional de Bellas Artes. http://www.gilberttoprado.net/assets/circuito_alameda_gttoprado_jlf.pdf (Consultado el 1.12.2021)

Prado, G. (2003). Arte telemática:dos intercâmbios pontuais aos ambientes virtuais multiusuário. São Paulo: Itaú Cultural. https://poeticasdigitais.files.wordpress.com/2009/09/ 2003-arte_telematica_dos_intercambios_pontuais_aos.pdf

Raffo, I. (2022) Intermitencias. Montevideo: Centro Cultural de España.

Restrepo, J.A., La Ferla, J., Religión Catódica. José Alejandro Restrepo. Buenos Aires: Espacio de Arte Fundación OSDE. http://www.historicoartefundacionosde.com.ar/backend/upload/evento/Espacio_de_Arte_Catalogos/restrepo.pdf (Consultado el 1.12.2021)

Suter, G., La Ferla, J. (2018). neoTrópico. Caja Negra y otros Microrelatos. Laboratorio Arte Alameda, Secretaría de Cultura. Ciudad de México: Instituto Nacional de Bellas Artes.

Recebido: 16 de novembro de 2021 . Aprovado: 16 de novembro de 2021. 